\title{
Examining the Relationship between Thinking Styles and Technological Pedagogical Content Knowledge of the Candidate Mathematics Teachers
}

\author{
Nuran Canbolat ${ }^{1}$, Ahmet Erdogan ${ }^{1}$, Derya Ozlem Yazlik $^{2}$ \\ ${ }^{1}$ Necmettin Erbakan University, Turkey \\ ${ }^{2}$ Nevsehir Hacı Bektas Veli University, Turkey \\ Correspondence: Derya Ozlem Yazlik, Nevsehir Hacı Bektas Veli University, Turkey.
}

Received: August 19, 2016

doi:10.11114/jets.v4i11.1819
Accepted: September 7, $2016 \quad$ Online Published: September 23, 2016

URL: http://dx.doi.org/10.11114/jets.v4i11.1819

\begin{abstract}
The aim of this research is measuring the technological pedagogical content knowledge of the candidate elementary mathematics teachers, identifying the thinking styles of the same candidates and finding out that whether there is a correlation or not. The research has the characteristics of a basic research to add new information to the scientific literature by examining the correlation. The study was carried out on 288 students from the Elementary Mathematics Teaching Department of the Education Faculty of Selcuk University at 2010-2011 academic years. As data collection tool, "Technological Pedagogical Content Knowledge Scale" was used for technological pedagogical content knowledge and "Sternberg-Wagner Thinking Styles Scale" was used for thinking styles. The SPSS program is used for the data analysis that gathered from the scales. According to the findings obtained at the end of the study; judicial, liberal and hierarchic thinking styles has a meaningful relationship with the sub-dimensions of technological pedagogical content knowledge according to the other thinking styles.
\end{abstract}

Keywords: thinking styles, technological pedagogical content knowledge, mathematics education

\section{Introduction}

Teacher has a key role on planning and maintaining the teaching classroom activities. Teacher's experience, competency and quality are also shaping that role (Demir \& Bozkurt, 2011). At first, the idea that teachers should only have content knowledge is supported, when the competence requirements of teachers are examined (Shulman, 1968; Turnuklu \& Yesildere, 2007). After that Shulman (1986) brought out a new thinking way to the knowledge that teachers needed for education by synthesizing the pedagogical knowledge and content knowledge, which is called Pedagogical Content Knowledge (PCK). Shulman (1968) define this pedagogical content knowledge as knowledge that dividing the specialist from the educator. According to that, knowing a subject very well is not enough to teach that subject well. According to Mishra and Koehler (2006), pedagogical content knowledge is organizing the content to ensuring a good teaching.

Using technological devices frequently with technological advances and including them to the education, it is expected from the teachers that they need to use technology as serving their subject's purpose by blending it with the pedagogy (Armstrong et al., 2005; Ertmer \& Ottenbreit-Leftwich, 2010; Demir et al., 2011; Sad \& Goktas, 2014). Teachers should have the pedagogical content knowledge and also necessary technological knowledge to integrate the technology to the teaching process successfully (Jang \& Tsai, 2012). That is why, as a result of expanding the pedagogical knowledge by including the technological knowledge the Technological Pedagogical Content Knowledge (TPACK) come out, which includes content knowledge, pedagogy knowledge and technological knowledge on its basics (Mishra \& Koehler, 2006). Niess (2005) defines the technological pedagogical content knowledge as the body of knowledge that teachers need for teaching with technology to the relevant level of class and subject.

Seven knowledge contents come up after the intersections of technological knowledge, pedagogical knowledge and content knowledge which are the basics of TPACK. These are: Content Knowledge (CK), Pedagogical Knowledge (PK), Technological Knowledge (TK), Pedagogical Content Knowledge (PCK), Technological Content Knowledge (TCK), Technological Pedagogical Knowledge (TPK) and Technological Pedagogical Content Knowledge (TPACK) (Harris, Mishra \& Koehler, 2006; Mishra \& Koehler, 2007). This structure which is placed on the basics of TPACK model has been showed on the Figure 1. 


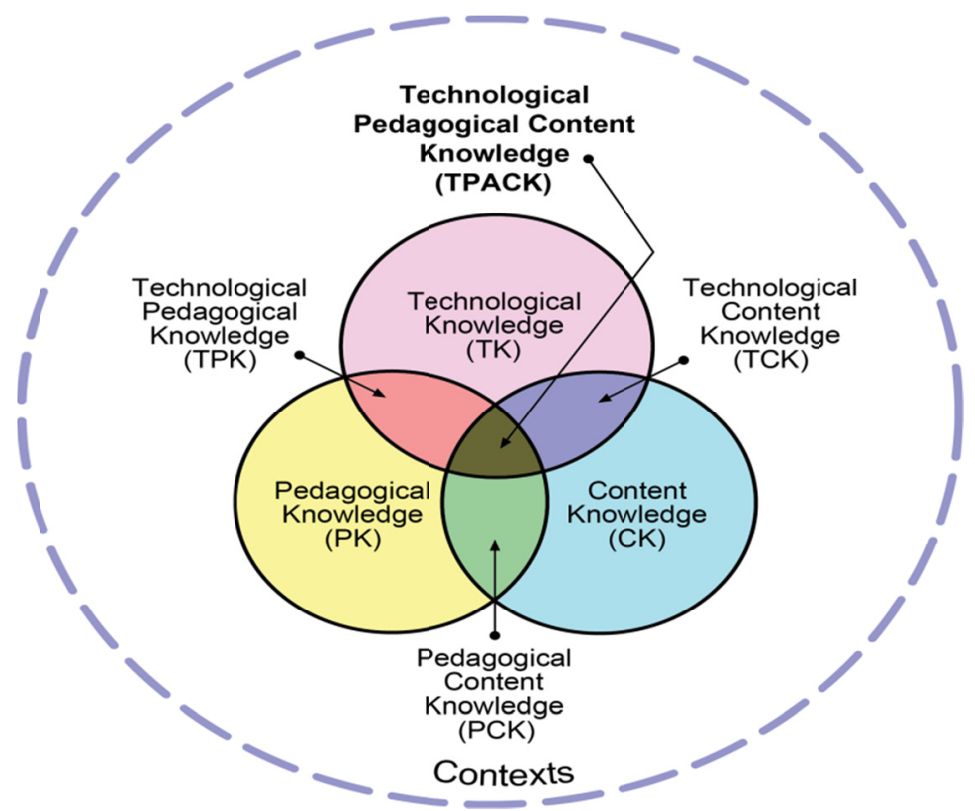

Figure 1. The Components of TPACK (http://tpack.org)

As it is seen on the Figure 1 there is three basic components called technology, pedagogy and content on the basics of TPACK model. Content knowledge is the knowledge that should have known for teaching the context (Harris, Mishra $\&$ Koehler, 2007). Pedagogical knowledge includes how students learn, teaching approaches, evaluation methods and general knowledge about different theories on learning (Shulman, 1986; Harris, Mishra \& Koehler, 2009). And technological knowledge includes technological literacy, using the technology on daily life and orientating the technological changes (Schmidt et al., 2009). With the intersection of content, technology and pedagogical knowledge, there are 4 more components comprise of. From them, pedagogical content knowledge is the knowledge that making the subject understandable for the ones who are learning (Niess, 2005). While technological pedagogical knowledge including the abilities to use technology, the various technologies that used in the learning and teaching fields and their technological components, the technological content knowledge is representing the knowledge about how context and technology is related to teaching (Mishra \& Koehler, 2005; Koehler, Mishra \& Yahya, 2007; Schmidt et al., 2009). Technological Pedagogical Content Knowledge is the very center with the interactions of content, technology and pedagogical knowledge. Technological Pedagogical Content Knowledge includes the knowledge that teaching the related target subjects with the necessary teaching techniques in an efficient way to the students' proper individual learning needs (Mishra \& Koehler, 2006). Recently, the necessity of using the technological resources in teaching and learning activities is emphasized continuously to improve the effectiveness and productivity on education (NCTM, 2000; MEB, 2013). Because of this, knowing only the technological knowledge by teachers is not enough to use technology in the classrooms with an effective and productive way. As it was emphasized on the above technology, pedagogy and content knowledge is related with each other and has a dynamic balance according to TPACK model. For a successful teaching with the technology this dynamic balance between the components should be built at all the time. As a result, the teachers should know the technological pedagogical content knowledge to use the technology in the classroom.

\subsection{Thinking Styles}

When the sufficiency of teachers is considered, it is seen that this is closely related to the thinking styles. Because thinking styles is closely related with the how the individuals get the knowledge and proceed (Sunbul, 2004). Sternberg (1997) describing the thinking styles as the way that chosen by individuals to use mind and knowledge depending onto Mental Self-government Theory. Thinking styles is also described by the Sternberg and Grigorenko (1997) as the thinking ways that individuals find it more reliable and usable for themselves. Thinking way is not ability but a choice in itself. So there are no good or bad styles only the differences. That is why thinking styles can change depending on the circumstances that the problem having in time (Sternberg, 1994).

Sternberg (1997) has identified totally thirteen thinking styles under the five dimensions that they called tendencies, extents, levels, forms and functions based on the Mental Self-government Theory. These dimensions and thinking styles has given detailed at Table 1. 
Table 1. The Thinking Styles and its Properties on the Mental Self-government Theory

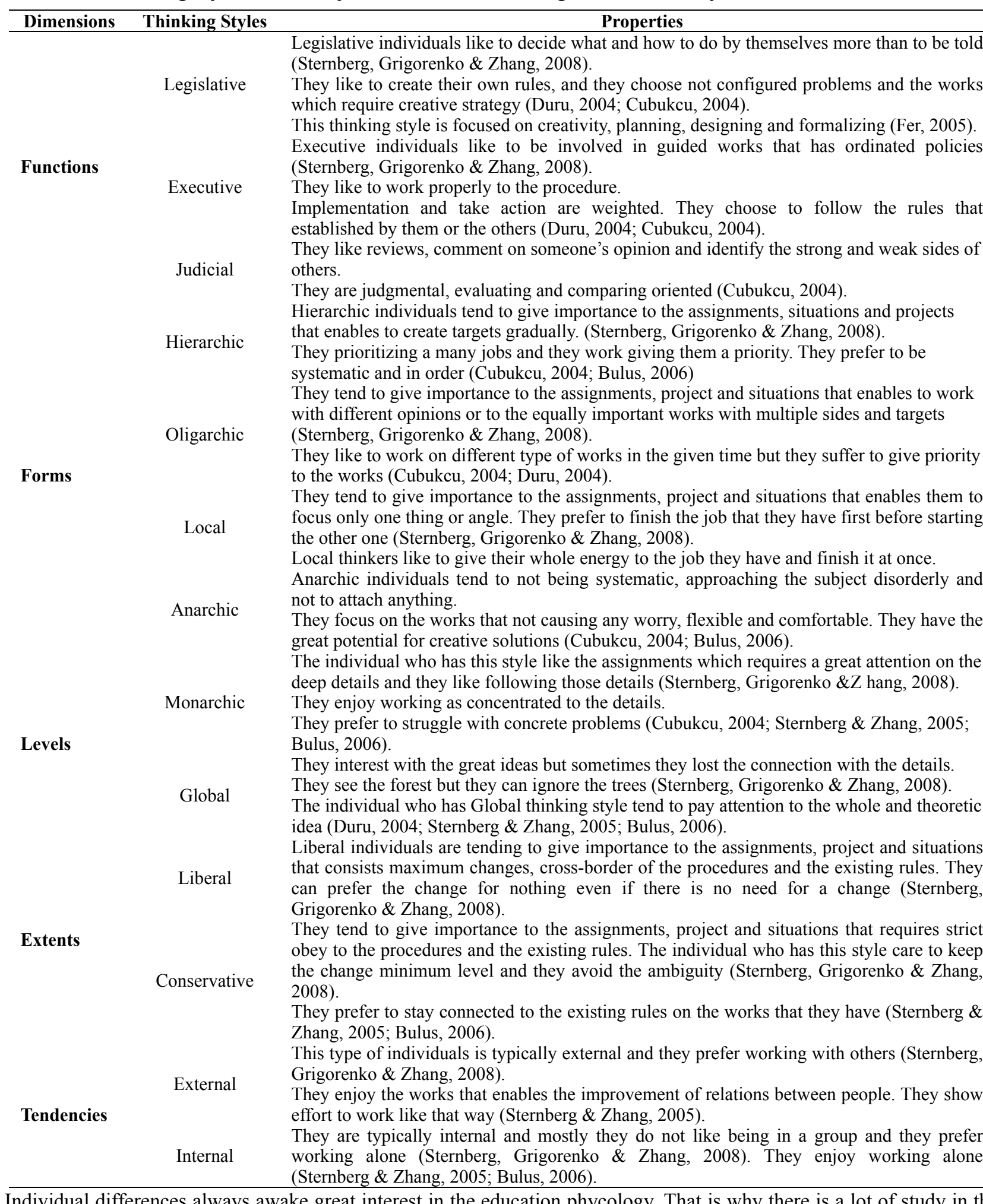

Individual differences always awake great interest in the education phycology. That is why there is a lot of study in the literature about individual differences like learning styles and thinking styles (Betoret, 2007). When the studies about the thinking styles are examined, it is seen that there are studies which consists of the thinking styles of teachers, candidate teachers and students (Zhang, 2004; Bulus, 2005; Artut \& Bal, 2008; Balgalmıs, 2006; Basol \& Turkoglu, 2009; Yildılar, 2010). Similarly, it is seen that there are also studies about using the technology in education by the teachers and candidate teachers who has Technological Pedagogical Content Knowledge related to their sufficiency (Kurt \& Akkoc, 2008; Selim, Tatar \& Oz, 2009; Erdogan, 2010; Erdogan \& Sahin, 2010; Kaya, Emre \& Kaya, 2010; 
Bozkurt \& Cilaydaroglu, 2011; Mutluoglu \& Erdogan, 2016). Also there is a need to know that which thinking style is related to which TPACK level for the teaching-learning process. That is why, it is very important that knowing and taking precaution about the deficiencies or uses of the technology, content and pedagogical knowledge that every teacher should require is coming from which thinking style.

\subsection{Aim of the Study}

The aim of this study is evaluating the Technological Pedagogical Content Knowledge (TPACK) of the candidate elementary mathematics teachers, identifying the thinking styles of the same teachers and examining the correlations of them. For this purpose, the following questions are asked;

a) Is there any relation between the thinking styles and TPACK levels of the candidate mathematics teachers?

b) Are thinking styles predict the TPACK levels of the candidate mathematics teachers?

\section{Method}

\subsection{Method of the Study}

Basic studies are done to examine the correlation, to develop new methods and briefly to add new information to the existing science knowledge (Kaptan, 1991). This study is a basic study that searching if there is a relation between thinking styles and TPACK levels of the candidate mathematics teachers and if there is, what kind of a relation it is.

\subsection{Study Group}

This study relied on 288 students from $3^{\text {rd }}$ and $4^{\text {th }}$ level of the Department of Elementary Mathematics Education in Education Faculty of Selcuk University at 2010-2011 academic year spring term. These students were chosen because they get the necessary content, formation and technological knowledge during their study period.

\subsection{Data Collection Tool}

On this study "Technological Pedagogical Content Knowledge Scale" used for technological pedagogical content knowledge and "Sternberg-Wagner Thinking Styles Scale" used for thinking styles as data collection tools. Technological Pedagogical Content Knowledge Scale is a scale that 5-ponit Likert type formed with totally 47 items which is under the 7 basic dimensions. The scale is adapted to Turkish by Sahin (2011), and validity and reliability of it has proved. The answers on the 5 Likert type are as " $1=$ not a clue", " $2=\mathrm{I}$ know a little", " $3=\mathrm{I}$ know intermediate", " $4=\mathrm{I}$ know at a good level" and " $5=\mathrm{I}$ know at a very good level". The sub-dimensions on the scale are technological knowledge (TK), pedagogical knowledge (PK), content knowledge (CK), technological pedagogical knowledge (TPK), technological content knowledge (TCK), pedagogical content knowledge (PCK) and technological pedagogical content knowledge (TPACK). The alpha coefficient of internal consistency is found at 0.96 as a result of this scale after applied to the study group. Sternberg-Wagner Thinking Styles Scale is adapted to Turkish by Bulus (2006) and it is a scale that 7-point Likert type with 65 items and 13 sub-dimensions. The answers are on this scale as " $1=$ it is not appropriate", " $2=$ not very appropriate", " $3=$ a little appropriate", " $4=$ fairly appropriate", " $5=$ appropriate", " $6=$ very appropriate" and "7=totally appropriate". The sub-dimensions of this scale are legislative thinking styles, executive thinking style, judicial thinking style, hierarchic thinking style, oligarchic thinking style, local thinking style, anarchic thinking style, monarchic thinking style, global thinking style, conservative thinking style, liberal thinking style, external thinking style and internal thinking style. The alpha coefficient of internal consistency is found at 0.93 as a result of this scale after applied to the study group.

\subsection{Data Analysis}

The SPSS program is used for analyzing the data gathered from the scales. To examine if there is a relation between thinking styles and TPACK level of the candidate mathematics teachers and if there is, what kind of a relation is it, Pearson's correlation coefficient and stepwise regression technique is used.

\section{Results}

First of all, the relation between the TPACK levels and thinking styles of the candidate teachers is examined at this section. The correlation values from the analysis are given on the Table 2 .

When Table 2 is examined, it is seen that the correlation is high between TPACK levels and legislative, judicial, hierarchic, anarchic, monarchic, internal and liberal thinking styles.

Multiple regression technique is applied to examine if thinking styles are predicting the TPACK levels of candidate mathematics teachers or not. Which thinking style is predicting which of the seven TPACK component is given on the following respectively. 
Table 2. The correlation values between the Thinking Styles and TPACK Levels

\begin{tabular}{llllllll}
\hline & $\mathrm{TK}$ & $\mathrm{CK}$ & $\mathrm{PK}$ & $\mathrm{PCK}$ & $\mathrm{TPK}$ & $\mathrm{TCK}$ & TPACK \\
\hline Legislative &,$- 15^{*}$ &,$- 21^{* *}$ &,$- 24^{* *}$ &,$- 26^{* *}$ &,$- 17^{* *}$ &,$- 20^{* *}$ &,$- 21^{* *}$ \\
Executive &,- 07 &,$- 29^{* *}$ &,$- 18^{* *}$ &,$- 16^{* *}$ &,- 11 &,$- 18^{* *}$ &,$- 16^{* *}$ \\
Judicial &,$- 15^{*}$ &,$- 29^{* *}$ &,$- 31^{* *}$ &,$- 29 * *$ &,$- 20^{* *}$ &,$- 28^{* *}$ &,$- 27^{* *}$ \\
Local &,- 05 &,$- 15^{*}$ &,- 10 &,- 09 &,- 03 &,- 08 &,- 06 \\
Hierarchic &,$- 17^{* *}$ &,$- 28^{* *}$ &,$- 35^{* *}$ &,$- 29 * *$ &,$- 19^{* *}$ &,$- 19 * *$ &,$- 21^{* *}$ \\
Oligarchic &,- 06 &,$- 23^{* *}$ &,$- 21^{* *}$ &,$- 18^{* *}$ &,$- 17^{* *}$ &,- 11 &,$- 18^{* *}$ \\
Anarchic &,$- 16^{* *}$ &,$- 15^{* *}$ &,$- 27^{* *}$ &,$- 21^{* *}$ &,$- 21^{* *}$ &,$- 20^{* *}$ &,$- 19^{* *}$ \\
Global &, 07 &,- 01 &, 03 &, 02 &, 01 &, 01 &, 01 \\
Monarchic &,$- 16^{* *}$ &,$- 16^{* *}$ &,$- 26^{* *}$ &,$- 19^{* *}$ &,$- 24^{* *}$ &,$- 18^{* *}$ &,$- 23^{* *}$ \\
Internal &,$- 18^{* *}$ &,$- 16^{* *}$ &,$- 28^{* *}$ &,$- 31^{* *}$ &,$- 24^{* *}$ &,$- 18^{* *}$ &,$- 23 * *$ \\
External &,$- 14^{*}$ &,$- 12^{*}$ &,- 09 &,- 08 &,- 08 &,- 07 &,- 09 \\
Liberal &,$- 21^{* *}$ &,$- 25^{* *}$ &,$- 32^{* *}$ &,$- 33^{* *}$ &,$- 22^{* *}$ &,$- 18^{* *}$ &,$- 23^{* *}$ \\
Conservative &, 03 &, 03 &, $17^{* *}$ &, $13^{*}$ &, 04 &, 02 &, 04 \\
\hline
\end{tabular}

$*: \mathrm{p}<.05 ; * *: \mathrm{p}<.01$

Table 3. Multiple Regression Analyze Results Related with Predicting Technological Knowledge

\begin{tabular}{ccccccc}
\hline Model $^{\text {a }}$ & $\mathbf{R}$ & $\mathbf{R}^{2}$ & Std. Err. & F & T & p \\
\hline 1 & 0.214 & 0.046 & 9.629 & 13.726 & 30.160 & 0.000 \\
\hline
\end{tabular}

a: dependent variable: Technology

b: predictor: Liberal

According to Table 3, it is seen that there is a low and meaningful relation between technology and liberal thinking styles, $\mathrm{R}=0.214, \mathrm{R}=0.046, \mathrm{~F}=13.726$. Liberal thinking style is predicting the technological knowledge with 0.05 ratio. Liberal thinking style is explaining the $\% 5$ of variance belonging to technological knowledge.

Table 4. Multiple Regression Analyze Results Related with Predicting Content Knowledge

\begin{tabular}{ccccccc}
\hline Model $^{\mathrm{a}}$ & $\mathbf{R}$ & $\mathbf{R}^{\mathbf{2}}$ & Std. Err. & $\mathbf{F}$ & $\mathbf{T}$ & $\mathbf{p}$ \\
\hline 1 & $0.286^{\mathrm{b}}$ & 0.082 & 3.314 & 25.486 & 34.991 & 0.000 \\
3 & $0.336^{\mathrm{c}}$ & 0.113 & 3.264 & 18.134 & 32.367 & 0.000 \\
4 & $0.359^{\mathrm{d}}$ & 0.129 & 3.240 & 14.038 & 26.689 & 0.000 \\
& $0.377^{\mathrm{e}}$ & 0.142 & 3.221 & 11.730 & 26.805 & 0.000 \\
\hline
\end{tabular}

a: dependent variable: content knowledge

${ }^{\mathrm{b}}$ : predictor: executive

${ }^{c}$ : predictor: executive, judicial

${ }^{\mathrm{d}}$ : predictor: executive, judicial, hierarchic

e: predictor: executive, judicial, hierarchic, oligarchic

When Table 4 is examined, it is seen that executive thinking style is predicting the content knowledge alone by 0.08 ratio; executive, judicial, hierarchic and oligarchic thinking styles are predicting it together by 0.14 ratio. While executive thinking style is explaining the $\% 8$ of variance belonging to content knowledge; executive and judicial both are explaining $\% 11$ of it; executive, judicial and hierarchic three of them are explaining $\% 13$ of it and executive, judicial, hierarchic and oligarchic four of them are explaining \%14 of it.

Table 5. Multiple Regression Analyze Results Related with Predicting Pedagogical Knowledge

\begin{tabular}{ccccccc}
\hline Model $^{\mathrm{a}}$ & $\mathbf{R}$ & $\mathbf{R}^{\mathbf{2}}$ & Std. Err. & $\mathbf{F}$ & $\mathbf{T}$ & $\mathbf{p}$ \\
\hline 1 & $0.348^{\mathrm{b}}$ & 0.121 & 3.829 & 39.332 & 36.756 & 0.000 \\
2 & $0.394^{\mathrm{c}}$ & 0.155 & 3.760 & 26.215 & 32.991 & 0.000 \\
3 & $0.418^{\mathrm{d}}$ & 0.175 & 3.723 & 20.070 & 27.119 & 0.000 \\
4 & $0.454^{\mathrm{e}}$ & 0.206 & 3.658 & 18.405 & 19.302 & 0.000 \\
5 & $0.448^{\mathrm{t}}$ & 0.200 & 3.665 & 23.733 & 20.429 & 0.000 \\
6 & $0.466^{\mathrm{g}}$ & 0.217 & 3.633 & 19.637 & 20.241 & 0.000 \\
\hline
\end{tabular}

a: dependent variable: pedagogical knowledge

b: predictor: oligarchic

c: predictor: oligarchic, liberal

d: predictor: oligarchic, liberal, monarchic

e. predictor: oligarchic, liberal, monarchic, conservative

f: predictor: oligarchic, monarchic, conservative 
g: predictor: oligarchic, monarchic, conservative, hierarchic

According to Table 5, oligarchic thinking style predicting the pedagogical knowledge alone by 0.12 ratio; oligarchic, monarchic, conservative and hierarchic thinking styles are together by 0.22 ratio. While oligarchic thinking style is explaining the $\% 12$ of variance belonging to pedagogical knowledge; oligarchic and liberal thinking styles both are explaining \%15 of it; oligarchic, liberal and monarchic three of them are explaining \%17 of it; oligarchic, liberal, monarchic and conservative four of them are explaining \%21 of it; oligarchic, monarchic and conservative three of them are explaining \%20 of it; oligarchic, monarchic, conservative and hierarchic four of them are explaining \%22 of it.

Table 6. Multiple Regression Analyze Results Related with Predicting Pedagogical Content Knowledge

\begin{tabular}{cccrccc}
\hline Model $^{\mathrm{a}}$ & $\mathbf{R}$ & $\mathbf{R}^{\mathbf{L}}$ & Std. Err. & $\mathbf{F}$ & $\mathbf{T}$ & $\mathbf{p}$ \\
\hline 1 & $0.328^{\mathrm{b}}$ & 0.108 & 4.177 & 34.496 & 36.498 & 0.000 \\
2 & $0.371^{\mathrm{c}}$ & 0.138 & 4.113 & 22.763 & 33.373 & 0.000 \\
3 & $0.389^{\mathrm{a}}$ & 0.151 & 4.088 & 16.849 & 32.698 & 0.000 \\
\hline
\end{tabular}

a dependent variable: Pedagogical Content Knowledge

: predictor: Liberal

: predictor: Liberal, internal

: predictor: Liberal, internal, oligarchic

According to Table 6 , liberal thinking style predicting the pedagogical content knowledge alone by 0.11 ratio; liberal, internal and oligarchic thinking styles are together by 0.15 ratio. While liberal thinking style is explaining the \%11 of variance belonging to pedagogical knowledge; liberal and internal thinking styles both are explaining $\% 14$ of it; liberal, internal and oligarchic three of them are explaining $\% 15$ of it.

Table 7. Multiple Regression Analyze Results Related with Predicting Technological Pedagogical Knowledge

\begin{tabular}{ccccccc} 
Model $^{\mathrm{a}}$ & $\mathbf{R}$ & $\mathbf{R}^{\mathbf{2}}$ & Std. Err. & $\mathbf{F}$ & $\mathbf{T}$ & $\mathbf{p}$ \\
1 & $0.237^{\mathrm{b}}$ & 0.056 & 3.034 & 17.085 & 26.244 & 0.000 \\
2 & $0.288^{\mathrm{c}}$ & 0.083 & 2.999 & 12.932 & 21.358 & 0.000 \\
\hline
\end{tabular}

a: dependent variable: technological pedagogical knowledge

b: predictor: internal

: : predictor: internal, monarchic

When Table 7 is examined, it is seen that internal thinking style is predicting the pedagogical technological knowledge alone by 0.06 ratio; internal and monarchic thinking styles are predicting it together by 0.08 ratio. While internal thinking style is explaining the $\% 6$ of variance belonging to technological pedagogical knowledge; internal and monarchic thinking styles both are explaining $\% 8$ of it.

Table 8. Multiple Regression Analyze Results Related with Predicting Technological Content Knowledge

\begin{tabular}{ccccccc}
\hline Model $^{\mathrm{a}}$ & $\mathbf{R}$ & $\mathbf{R}^{\mathbf{L}}$ & Std. Err. & $\mathbf{F}$ & $\mathbf{T}$ & $\mathbf{p}$ \\
\hline 1 & $0.248^{\mathrm{b}}$ & 0.081 & 2.894 & 25.093 & 26.740 & 0.000 \\
\hline
\end{tabular}

a: dependent variable: technological content knowledge

${ }^{\mathrm{b}}$ : predictor: judicial

According to Table 8 , judicial thinking style predicting the technological content knowledge by 0.08 ratio. Judicial thinking style is explaining the $\% 8$ of variance belonging to technological content knowledge.

Table 9. Multiple Regression Analyze Results Related with Predicting Technological Pedagogical Content Knowledge

\begin{tabular}{ccccccc} 
Model $^{\mathrm{a}}$ & $\mathbf{R}$ & $\mathbf{R}^{2}$ & Std. Err. & $\mathbf{F}$ & $\mathbf{T}$ & $\mathbf{p}$ \\
1 & $0.273^{\mathrm{b}}$ & 0.075 & 3.577 & 23.025 & 27.929 & 0.000 \\
2 & $0.309^{\mathrm{c}}$ & 0.095 & 2.542 & 15.030 & 24.635 & 0.000 \\
\hline
\end{tabular}

a: dependent variable: technological pedagogical content knowledge

b: predictor: judicial

c: predictor: judicial, internal

According to Table 9, judicial thinking style predicting the technological pedagogical content knowledge alone by 0.08 ratio; judicial and internal thinking styles are predicting it together by 0.10 ratio. While judicial thinking style is explaining the $\% 8$ of variance belonging to technological pedagogical content knowledge; judicial and internal thinking styles both are explaining $\% 10$ of it.

\section{Discussion}

What kind of a relation is there between thinking styles and TPACK levels of the candidate mathematics teachers and 
which thinking styles are predicting the seven knowledge levels of the technological pedagogical content knowledge are examined in this study. The findings gathered from seven sub-dimensions of technological pedagogical content knowledge are evaluated in this section.

According to results of this study, it is found out that the candidate teachers who have liberal thinking styles have more technological knowledge. Liberal individuals are tending to give importance to the assignments, project and situations that consists maximum changes, cross-border of the procedures and the existing rules (Sternberg, Grigorenko \& Zhang, 2008). It can be said that because the candidates who have liberal thinking styles are more open to the changings and innovations, their technological knowledge level is higher and they can use technology better to create something.

It is known that executive individuals are tending to give importance to working by rules with the assignments and procedures that have structural integrity (Sternberg, Grigorenko \& Zhang, 2008). The other result gathered from this study is showing us that the executive candidate teachers who like to work with procedures on the works that includes regular guidelines are predicting the content knowledge with higher level which requires same order and complete experience. It can be said that this result is come up because both are having the same order and principles. In addition to that, judicial, hierarchic and oligarchic thinking styles are predicting the content knowledge with different ratios. It is known that while oligarchic candidate teachers are tending to give importance to assignments that requires being done progressively, the judicial candidates are tending to give importance to the ones that requires evaluation, analyze, comparison and distinction (Cubukcu, 2004; Sternberg, Grigorenko \& Zhang, 2008). There is also a stage in mathematics content knowledge specifically. Ultimately mathematics' subjects are the subjects that require to be built on each other. It is impossible to learn something without knowing the other things and impossible to discover whole mathematics without any comparison or connection. So it can be said that to have good mathematics content knowledge, a structural integrity, evaluation and making connection between each subjects by progressing incrementally are necessary.

Pedagogical knowledge is a teacher's deep knowledge about the methods, implementations and learning processes which includes aims, targets and values of education (Mishra \& Koehler, 2006). One other findings of this study is that the most effective thinking style on pedagogical knowledge is hierarchic thinking style and besides that liberal, oligarchic and monarchic thinking styles are predicting the pedagogical knowledge with certain ratios. One of the important specialty that teachers should have is preparing the teaching process appropriate and effective way. For that the teacher should analyze the environment, students and time very well and identify the appropriate methods and techniques by taking into consideration of them. When the mathematics subjects considered, the plans should be done incrementally from the easy one to the hard one in order of subjects, formulas and information of topics that complement each other; if there are deficiencies places, repetition must be done to renew the old knowledge. After that the implementation of the decided process starts. Here according to our constructivist education system students should be evaluated personally not generally and the methods should be identified which the students can be most active. Of course for that teachers should keep pace with the changes as the century requires and keep away from the conservative thinking types and be with the liberal thinking types. So we can say that when you consider the content of the pedagogical knowledge, hierarchic, liberal, oligarchic and monarchic thinking styles are affecting this kind of knowledge with high level.

Pedagogical content knowledge is the knowledge about how pedagogy and content unite in an effective way (Shulman, 1986). The findings from the results of the study show that the most effective thinking style on the pedagogical content knowledge is liberal thinking style. Besides that, internal and hierarchic thinking styles are predicting the pedagogical content knowledge with a high ratio. It can be said that liberal thinking individuals know better how they will plan the lesson according to subject's content than the other individuals who has different thinking styles. Also the other two thinking styles played an important role for explaining the pedagogical content knowledge. Independent from these results, it can be said that the individuals who likes to work alone and works progressively on a subject with an order and principle are going to be good teachers on sharing their knowledge. As it is seen on the above findings that hierarchic thinking style is effective both on the pedagogical knowledge and content knowledge already.

Technological pedagogical knowledge is an understanding that how teaching changes when certain technologies used certain ways. This includes knowing the relationship between appropriate pedagogical designs, strategies and contents, benefits and limitations of the fields that some technological tools used (Mishra \& Koehler, 2009). Most of the technological tools have an easy usage with their visuality and speeds on the mathematics subjects. But here the important thing is to make the integrity between the level of learner and the method to be used according to its structure. In our study, when we look at the thinking styles that effective on this knowledge level, we see internal and monarchic thinking styles. It can be said that technological pedagogical knowledge level improves depending on the individuals' own studies and improvement. Because technological pedagogical knowledge requires to know yourself, take a step after examining the cases one by one, analyzing the subjects well and be aware of what you can. That is why, it can be 
said that internal and monarchic thinking styles are explaining the technological pedagogical knowledge with an important scale.

Technological content knowledge states the information about how technology can be used to find the new ways of the scope of learning (Niess, 2005). The findings from the results of the study show that the most effective thinking style on the technological content knowledge is judicial thinking style. That means a part of the technological content knowledge is explained by judicial thinking style. The abstract mathematics subjects which is hard to learn by students can be teach more easily with a good level of technological knowledge and also with this knowledge it may have been open a door to new subjects and different formulas. Because before the operations, individuals need to understand the content, picture this in his mind and examine it. Some of the computer algebra systems that we use frequently in these days are giving the analyzed, modeling and generalizing opportunities to the teachers by doing these operations swiftly. It is known that the judicial individuals giving importance to the judging the existing rules, comparing and analyzing the cases and evaluating the rules and procedures (Sternberg, Grigorenko \& Zhang, 2008). That is why, it can be said that judicial thinking style is explaining a part of the technological content knowledge.

Technological pedagogical content knowledge which occurred from the relation between content, pedagogy and technological knowledge is forming the basics of a meaningful and sufficient teaching based on technology. Technological pedagogical content knowledge is seen as an organizing structure to progress the education technology development programs for teachers. At the end of this study, it is seen that the most effective thinking style to explain this knowledge level is judicial thinking style. That means a part of the technological pedagogical content knowledge is explained by judicial thinking style. Also internal thinking style is predicting this type of knowledge. According to this result, it can be said that the candidate teachers who gives importance to judging different opinions, comparing and analyzing the facts, examining the rules and procedures and likes to work independent has a higher level knowledge on the technological pedagogical content knowledge which is the interaction of three types of knowledge.

\section{Conclusion and Recommendations}

According to the result of the study, it is seen that the thinking styles of the candidate teachers and their technological pedagogical content knowledge levels are related with each other. It was determined that the following thinking styles are effective predictors on the following knowledge; liberal thinking style is on the technological knowledge; judicial, executive, hierarchic and oligarchic thinking styles are on the content knowledge; liberal, internal and oligarchic thinking styles are on the pedagogical content knowledge; internal and monarchic thinking styles are on the technological pedagogical knowledge; judicial thinking style is on the technological content knowledge; judicial and internal thinking styles are on the technological pedagogical content knowledge. And it concluded that liberal, judicial and hierarchic thinking styles are the best explaining thinking styles of the dimensions of technological pedagogical content knowledge.

Following recommendations are done according to the finding of the study:

1. Pedagogy lessons should be on the programs of candidate teachers every year, not just on the last year.

2. The following skills should be given to the candidate teachers; knowing which thinking style they are using more, being more flexible on the thinking styles and changing the not enough effective thinking styles on the technological pedagogical content knowledge with the more effective and functional ones.

3. For having the more successful and qualified teachers, educational institutions should give space to the ones with the liberal, judicial and hierarchic thinking styles instead of the other thinking styles which are less related with the technological pedagogical content knowledge.

4. Every individual has its own thinking style. The teaching environments should be organized by taking the different type of thinking styles every individual has on the teaching-learning process into consideration.

\section{References}

Armstrong, V., Barnes, S., Sutherland, R., Curran, S., Mills, S., \& Thompson, I. (2005). Collaborative research methodology for investigating teaching and learning: the use of interactive white board technology. Educational Review, 57(4), 457-469. http://dx.doi.org/10.1080/00131910500279551

Artut, D. P., \& Bal, A. P. (2006). Mathematics achievement and thinking style of students. XV. National Mugla Education Sciences Congress, Mugla.

Balgalmis, E. (2006). Comparison to thinking styles of high school students. XV. National Mugla Education Sciences Congress, Mugla. 
Basol, G., \& Turkoglu, E. (2009). The relationship between the locus of control and thinking styles of teacher candidates. Journal of Human Sciences, 6(1), 732-757.

Betoret, F. D. (2007). The influence of students' and teachers' thinking styles on student course satisfaction and on their learning process. Educational Psychology, 27(2), 219-234. http://dx.doi.org/10.1080/01443410601066701

Bozkurt, A., \& Cilavdaroglu, A. K. (2011). Mathematics and classroom teachers' perceptions of technology use and integration into their instruction. Kastamonu Education Journal, 19(3), 859-870.

Bulus, M. (2005). The investigation of the thinking styles profile of students in the department of elementary education. Ege Journal of Education, 6(1), 1-24.

Bulus, M. (2006). Assessment of Thinking Styles Inventory, academic achievement and student teachers' characteristics. Education and Science, 31(139), 35-48.

Cubukcu, Z. (2004). Determine the thinking styles of teacher candidates. Trakya University Journal of Social Science, $5(2), 87-106$.

Demir, S., \& Bozkurt, A. (2011). Primary mathematics teachers' views about their competencies concerning the integration of technology. Elementary Education Online, 10(3), 850-860.

Demir, S., Ozmantar, M.F., Bingölbali, E., \& Bozkurt, A. (2011). Sınıf Ogretmenlerinin teknoloji kullanımlarının irdelenmesi. 5th International Computer \& Instructional Technologies Symposium, Firat University, Elazıg, Turkey.

Duru, E. (2004). Thinking styles: theoretical and conceptual framework. Eurasian Journal of Educational Research, 14, 171-186.

Erdogan, A. (2010). Variables that affect math teacher candidates' intentions to integrate computer assisted mathematics education (CAME). Education, 131(2), 295-305.

Erdogan, A., \& Sahin, I. (2010). Relationship between math teacher candidates' technological pedagojical and content knowledge and achievement levels. Procedia Social and Behavioral Sciences, 2, 2707-2711. http://dx.doi.org/10.1016/j.sbspro.2010.03.400

Ertmer, P. A., \& Ottenbreit-Leftwich, A. T. (2010). Teacher technology change: How knowledge, confidence, beliefs, and culture intersect. Journal of Research on Technology in Education, 42(3), 255-284. http://dx.doi.org/10.1080/15391523.2010.10782551

Fer, S. (2005). Validity and reliability of the thinking styles inventory. Educational Sciences: Theory and Practice, 5(1), 31-68.

Harris, J. B., Mishra, P., \& Koehler, M. J. (2007). Teachers' technological pedagogical content knowledge: Curriculum-based technology integration reframed. Paper presented at the American Educational Research Association Conference, Chicago, IL.

Harris, J., Mishra, P., \& Koehler, M. (2009). Teachers' technological pedagogical content knowledge and learning activity types: Curriculum-based technology integration reframed. Journal of Research on Technology in Education, 41(4), 393-416. http://dx.doi.org/10.1080/15391523.2009.10782536

Head Council of Education and Morality (2013). Mathematics 9-12. Classes Curriculum Book. Ankara, National Educational Pub.

Jang, S., \& Tsai, M. (2012). Exploring the tpack of Taiwanese elementary mathematics and science teachers with respecttouse of interactive white boards. Computers \& Education, 59(2), 327-338. http://dx.doi.org/10.1016/j.compedu.2012.02.003

Kaptan, S. (1991). Scientific research and statistics techniques. Ankara: Tekısık Web of set Facility.

Kaya, Z., Emre, I., \& Kaya, O. N. (2009). Determination the confidence level of teacher candidates in terms of technological pedagogical content knowledge. 9. National Elementary Teaching Training Symposium, Elazıg.

Koehler, M. J., Mishra, P., \& Yahya, K. (2007). Tracing the development of teacher knowledge in a design seminar: Integrating content, pedagogy and technology. Computers \& Education, 49, 740-762.

http://dx.doi.org/10.1016/j.compedu.2005.11.012

Kurt, S., \& Akkoc, H. (2008). Mathematics teaching practice of teacher candidates with the graphing calculator: increasing and decreasing functions and inverse functions. II. International Computer and Instructional Technologies Symposium, Kusadas1. 
Mishra, P., \& Koehler, M. J. (2006). Technological pedagocical content knowledge: a framework for teacher knowledge. Teacher College Record, 108(6), 1017-1054. http://dx.doi.org/10.1111/j.1467-9620.2006.00684.x

Mutluoğlu, A., \& Erdogan, A. (2016). Examining primary Mathematics teachers' Technological Pedagogical Content Knowledge (TPACK) levels according to their preferred teaching styles. OPUS- International Journal of Society Researches, 6(10), 100-124.

NCTM (2000). Principles and standards for school mathematics. Reston, VA: National Council of Teachers of Mathematics (NCTM) Pub.

Niess, M. L. (2005). Preparing teachers to teach science and mathematics with technology: Developing a technology pedagogical content knowledge. Teaching and Teacher Education, 21, 509-523. http://dx.doi.org/10.1016/j.tate.2005.03.006

Sad, S. N., \& Goktas, O. (2014). Preservice teachers' perceptions about using mobile phones and laptops in education as mobile learning tools. British Journal of Educational Technology-BJET, 45(4), 606-618. http://dx.doi.org/10.1111/bjet.12064

Sahin, I. (2011). Development of survey of technological pedagogical and content knowledge (Tpack). The Turkish Online Journal of Educational Technology, 10(1).

Schmidt, D. A., Baran, E., Thompson, A. D., Mishra, P., Koehler, M. J., \& Shin, T. S. (2009). Technological Pedagogical Content Knowledge (TPACK): The development and validation of an assessment instrument for pre-service teachers. Journal of Research on Technology in Education, 42(2), 27. http://dx.doi.org/10.1080/15391523.2009.10782544

Selim, Y., Tatar, E., \& Oz, R. (2009). An investigation of instructional materials prepared by mathematics preservice teachers on T-PCK model. Erzincan University Journal of Science and Technology, 2(2), 239-251.

Shulman, L. S. (1986). Those who understand. Knowledge growth in teaching. Educational Researcher, 15, 4-14. http://dx.doi.org/10.3102/0013189X015002004

Sternberg R. J., \& Zhang L. F. (2005). A threefold model of intellectual styles, Educational Psychology Review, 17(1), 1-53. http://dx.doi.org/10.1007/s10648-005-1635-4

Sternberg R. J., Grigorenko E. L., \& Zhang L. F. (2008). Styles of learning and thinking matter in instruction and assessment. Perspectives on Psychological Science, 6, 486-506. http://dx.doi.org/10.1111/j.1745-6924.2008.00095.x

Sternberg, R. J. (1994). Thinking styles: Theory and assessment at the interface between intelligence and personality, in: R. J. Sternbergand P. Ruzgıs (Eds) Intelligence and Personality, 169-187. New York: Cambridge University Press.

Sternberg, R. J. (1997). Thinking styles. Cambridge: Cambridge University Press. http://dx.doi.org/10.1017/CBO9780511584152

Sternberg, R. J., \& Grigorenko, E. L. (1997). Are Cognitive styles still in styles. American Psychologist, 52, 700-712. http://dx.doi.org/10.1037/0003-066X.52.7.700

Sunbul, A. M. (2004). The validity reliability of the thinking styles scale. Education and Science, 29(132), 25-42.

Turknuklu, E., \& Yesildere, S. (2007). The pedagogical content knowledge in mathematics: Pre-service primary mathematics teachers' perspectives in Turkey. Issues in the Undergraduate Mathematics Preparation of School Teachers: The Journal, 1, 1-13.

Yildizlar, M. (2010). Thinking styles of candidate teachers who come from different cultures. Hacettepe University Journal of Education, 39, 383-393

Zhang, L. F. (2004). Revisiting the predictive power of thinking styles for academic performance. The Journal of Psychology, 4, 351-370. http://dx.doi.org/10.3200/JRLP.138.4.351-370 